\author{
H. C. J. Ottenheym, ${ }^{1}$ T. F. Spande, and B. Witkop* \\ Contribution from the Laboratory of Chemistry, National Institute of Arthritis, \\ Metabolism and Digestive Diseases, National Institutes of Health, \\ Bethesda, Maryland 20014. Received August 11, 1972
}

\begin{abstract}
The addition of $\alpha$-halo- $\alpha$-aminoacyl chlorides to ethyl indolenine-2-carboxylates followed by reaction with sulfur nucleophiles and a final ring closure provides a convenient and new synthetic scheme to analogs of gliotoxin, the simplest of the natural products containing the epidithiodiketopiperazine system. Illustrative of this approach, adducts of ethyl 3,3-dimethylindolenine-2-carboxylate (17) with acid chlorides, $\alpha$-halo acid chlorides, and $N$-trifluoroacetyl- $\alpha, \alpha$-dichlorosarcosyl chloride (44) have been studied. The last adduct when treated with a sulfide-polysulfide mixture gave a monosulfide 49 (30\% yield) but no disulfide 50 . Reduction of 49 with $\mathrm{NaCNBH}_{3}$ proceeded stereoselectively to afford mainly the secogliotoxin analog $\mathbf{5 1}$ in addition to the diastereoisomer $\mathbf{5 2}$. Cyclization of this mixture presumably led to the strained epimonothiodiketopiperazine 41, which easily opened to the isomeric lactam $\mathbf{5 5}$ in addition to lactam 56 formed by epimerization.
\end{abstract}

$\mathrm{T}^{\mathrm{h}}$ he number of natural products containing the epidithiodiketopiperazine ring 1 continues to grow with the recent reports on the two fungal metabolites chaetocin (2) ${ }^{2}$ and verticillin A (3). ${ }^{3}$ Both are highly active against gram-positive bacteria. Chaetocin is cytostatic but lacks antiviral activity, while verticillin A is cytotoxic and active against mycobacteria. Other members of this group of fungal metabolites are the sporidesmins A through $G(4-6)^{4-10}$ several of which possess potential antibacterial activity, the aranotins (7-9) ${ }^{11-15}$ and apoaranotins $(10-11)^{16}$ which have no antibacterial but do have potent antiviral activity, ${ }^{14}$ gliotoxin (12a), ${ }^{4,17}$ an antibiotic, antifungal and antiviral agent, and dehydrogliotoxin (12b) ${ }^{18}$ with antibacterial activity.

Two other fungal metabolites, chetomin $\left(\mathrm{C}_{81} \mathrm{H}_{30}\right.$ $\left.\mathrm{N}_{6} \mathrm{O}_{6} \mathrm{~S}_{4}\right)^{19}$ and oryzachlorin $\left(\mathrm{C}_{26} \mathrm{H}_{31} \mathrm{~N}_{2} \mathrm{O}_{8} \mathrm{~S}_{2} \mathrm{Cl}\right),{ }^{20}$ of un-

(1) Associate in the Visiting Program of the USPHS, 1970-1971; Department of Organic Chemistry, University at Nijmegen, Toernooiveld, Nijmegen, The Netherlands.

(2) D. Hauser, H. P. Weber, and H. P. Sigg, Helv. Chim. Acta, 53, $1061(1970)$

(3) H. Minato, M. Matsumoto, and T. Katayama, Chem. Commun., 44 (1971).

(4) A. F. Beecham, J. Fridrichsons, and A. M. Mathieson, Tetrahedron Lett., 3131 (1966).

(5) N. Finch, C. W. Gemenden, I. H. C. Hsu, and W. I. Taylor, J. Amer. Chem. Soc., 85, 1520 (1963).

(6) R. Hodges, J. S. Shamon, and A. Taylor, J. Chem. Soc. C, 1803 (1966).

(7) R. Hodges and J. S. Shannon, Aust. J. Chem., 19, 1059 (1966).

(8) W. D. Jamieson, R. Rahman, and A. Taylor, J. Chem. Soc. C, 1564 (1969).

(9) D. Brewer, R. Rahman, S. Safe, and A. Taylor, Chem. Commun., 1571 (1968)

(10) R. Rahman, S. Safe, and A. Taylor, J. Chem. Soc. C, 1665 (1969); E. Francis, R. Rahman, S. Safe, and A. Taylor, ibid., 470 (1972).

(11) R. Nagarajan, L. L. Huckstep, D. H. Lively, D. C. DeLong, M. M. Marsh, and N. Neuss, J. Amer. Chem. Soc., 90, 2980 (1968).

(12) R. Nagarajan, N. Neuss, and M. M. Marsh, ibid., 90, 6518 (1968).

(13) P. A. Miller, P. W. Trown, W. Fulmor, G. O. Morton, and J. Karliner, Biochem. Biophys. Res. Commun., 33, 220 (1968).

(14) D. B. Cosulich, N. R. Nelson, and J. H. van den Hende, $J$. Amer. Chem. Soc., 90, 6519 (1968).

(15) J. W. Moncrief, ibid., 90, 6517 (1968).

(16) N. Neuss, R. Nagarajan, B. B. Molloy, and L. L. Huckstep, Tetrahedron Lett., 4467 (1968).

(17) M. R. Bell, J. R. Johnson, B. S. Wildi, and R. B. Woodward, J. Amer. Chem. Soc., 80, 1001 (1958).

(18) G. Lowe, A. Taylor, and L. C. Vining, J. Chem. Soc. C, 1799 (1966).

(19) S. Safe and A. Taylor, J. Chem. Soc. C, 472 (1972).

(20) A. Kato, T. Salki, S. Suzuki, K. Ando, G. Tamura, and K. Arima, Jap. J. Antibiot. 22, 322 (1969). known structure, probably contain the epidithiodiketopiperazine ring. The former is active against grampositive bacteria ${ }^{19}$ and viruses ${ }^{21}$ while the latter has only antifungal and antiviral activity. ${ }^{20}$

The mechanism of antiviral action of gliotoxin ${ }^{22}$ and aranotin $^{13}$ depends upon the specific inhibition of RNA-dependent DNA polymerases from tumor-producing viruses or blocking of the synthesis of viral $\mathrm{RNA}^{21}$ in the case of chetomin.

Several syntheses of simple epidithiodiketopiperazines have been reported, ${ }^{21,23-25}$ which feature the addition of sulfur substituents to a preformed diketopiperazine. Surprisingly, the simple model $\mathbf{1 a}$ is highly active in inhibiting viral RNA synthesis, ${ }^{21}$ in support of the view ${ }^{26}$ that the activity of the more complex natural products resides in the epidithiodiketopiperazine ring.

Another approach to this ring system started with 2benzamido-2-mercaptopropanoic acid (13) as a possible precursor. ${ }^{27}$

The drastic reaction conditions of all of these methods preclude their successful extension to the polycyclic epidithiodiketopiperazines. A synthetic approach of general applicability, we felt, would feature the initial construction of the disulfide bridge and then ring closure to a bridged diketopiperazine.

The addition of acyl chlorides to indolenines (Chart 1), a reaction first reported by Leuchs, who studied compounds 14-16, ${ }^{28-30}$ served as our first step.

The 2-chloro substituent in Leuchs' adducts $\mathbf{1 8 - 2 0}$ is known to undergo easy nucleophilic displacement, and

(21) P. W. Trown, Biochem. Biophys. Res. Commun., 33, 402 (1968). (22) P. A. Miller, K. P. Milstrey, and P. W. Trown, Science, 159. 431 (1968).

(23) H. Poisel and U. Schmidt, Angew. Chem., 83, 114 (1971); Chem. Ber., 104, 1714 (1971); 105, 625 (1972); E. Oehler, H. Poisel, F. Tataruch, and U. Schmidt, ibid., 105, 635 (1972); E. Oehler, F. Tataruch, and U. Schmidt, ibid., 105, 3658 (1972).

(24) T. Hino and T. Sato, Tetrahedron Lett., 3127 (1971)

(25) S. G. Svokos and R. B. Angier, German Patent 2,029,306; Chem. Abstr., 74, 53845 (1971).

(26) D. Brewer, D. E. Hannah, and A. Taylor, Can.J. Microbiol., 12, 1187 (1966).

(27) P. M. Pojer and I. D. Rae, Tetrahedron Lett., 3077 (1971); Aust. J. Chem., 25, 1737 (1972); cf. A. Kaneda and R. Sud, Bull. Chem. Soc. Jap., 43, 2159 (1970).

(28) H. Leuchs, A. Heller, and A. Hoffmann, Chem. Ber., 62, 871 (1929).

(29) H. Leuchs, G. Wulkow, and H. Gerland, ibid., 65, 1586 (1932)

(30) H. Leuchs and A. Schlötzer, ibid., 67, 1572 (1934). 
<smiles>[R]N1C(=O)C2([R7])SSC1([R7])C(=O)N2[R]</smiles>
1 2

a, $\mathbf{R}=\mathbf{R}^{\prime}=\mathrm{CH}_{3}$; $\mathrm{R}^{\prime \prime}=\mathrm{R}^{\prime \prime \prime}=\mathrm{H}$<smiles>CN1C(=O)C23SSC1(C)C(=O)N2C1Nc2ccccc2C1(C)C3O</smiles>

3

verticillin A

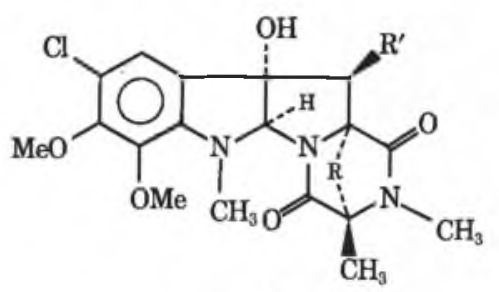

4

sporidesmin

A, $\mathrm{R}^{\prime}=\mathrm{OH} ; \mathrm{R}=\mathrm{S}-\mathrm{S}$ (active) ${ }^{4}$

B, $\mathbf{R}^{\prime}=\mathrm{H} ; \mathrm{R}=\mathrm{S}-\mathrm{S}$ (active) $^{5}$

$\mathrm{D}, \mathbf{R}^{\prime}=\mathrm{OH} ; \mathrm{R}=\mathrm{SCH}_{3}, \mathrm{CH}_{3} \mathrm{~S}$ (inactive) $^{8}$

$\mathbf{E}, \mathbf{R}^{\prime}=\mathbf{O H} ; \mathbf{R}=\mathbf{S}-\mathbf{S}-\mathbf{S}$ (active) $^{9}$

$\mathrm{G}, \mathrm{R}^{\prime}=\mathrm{OH} ; \mathrm{R}=\mathrm{S}_{4}{ }^{10}$<smiles>C=C1C(=O)N(C)C(C)([C@H](C)O)C(=O)N1C</smiles>

5

sporidesmin F (inactive) $^{8}$

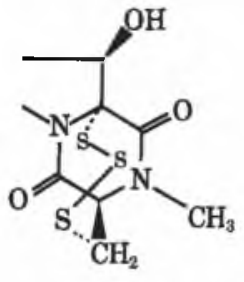

6

sporidesmin $\mathbf{C}$ (active) $^{7}$

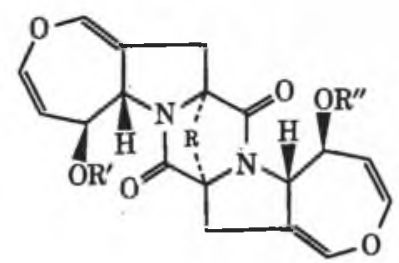

7, aranotin; $R^{\prime}=H, R^{\prime \prime}=A c ; R=S-S$ (active)

8, acetylaranotin; $\mathbf{R}^{\prime}=\mathrm{R}^{\prime \prime}=\mathrm{Ac} ; \mathrm{R}=\mathrm{S}-\mathrm{S}$ (active)

9, bisdethiodi(methylthio)acetylaranotin;

$\mathbf{R}^{\prime}=\mathbf{R}^{\prime \prime}=\mathrm{Ac} ; \mathrm{R}=\mathrm{CH}_{3} \mathrm{~S}, \mathrm{SCH}_{3}$ (inactive)

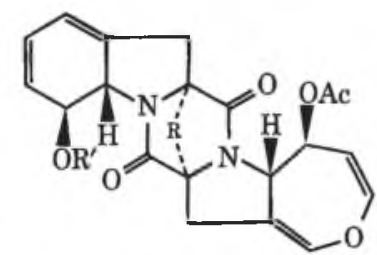

10, apoaranotin; $\mathrm{R}^{\prime}=\mathrm{H} ; \mathrm{R}=\mathrm{S}-\mathrm{S}$ (active)

11, bisdethiodi(methylthio)acetylapoaranotin; $\mathbf{R}^{\prime}=\mathrm{Ac} ; \mathrm{R}=-\mathrm{SCH}_{3}, \mathrm{CH}_{3} \mathrm{~S}-$ (inactive)<smiles>CN1C(=O)C23CC4=CC=C[C@H](O)C4N=C2SS13C(=O)O</smiles>

12a, gliotoxin<smiles>CN1C(=O)C23Cc4cccc(O)c4N2C(=O)C1(CO)SS3</smiles>

$12 \mathrm{~b}$, dehydrogliotoxin<smiles>CCC(=O)NC(C)([Hg])C(=O)O</smiles>

Chart I<smiles>[R]C1=Nc2ccccc2C1(C)C</smiles>

$14, \mathrm{R}=\mathrm{H}$

15, $\mathrm{R}=\mathrm{CH}_{3}$

16, $\mathrm{R}=\mathrm{C}_{6} \mathrm{H}_{5}$

17, $\mathrm{R}=\mathrm{CO}_{2} \mathrm{C}_{2} \mathrm{H}_{5}$
$\underline{\mathrm{R}^{\prime} \mathrm{COCl}}$<smiles>[R]C(=O)N1c2ccccc2C(C)(C)C1([R])Cl</smiles>

18, $\mathrm{R}=\mathrm{H} ; \mathrm{R}^{\prime}=\mathrm{CH}_{3}, \mathrm{C}_{6} \mathrm{H}_{5}$, or $p-\mathrm{NO}_{2} \mathrm{C}_{6} \mathrm{H}_{5}$

$19, \mathrm{R}=\mathrm{CH}_{3} ; \mathrm{R}^{\prime}=\mathrm{CH}_{3}$ or $\mathrm{C}_{6} \mathrm{H}_{5}$

20, $\mathrm{R}=\mathrm{C}_{6} \mathrm{H}_{5} ; \mathrm{R}^{\prime}=\mathrm{C}_{6} \mathrm{H}_{5}$

21, $\mathrm{R}=\mathrm{CO}_{2} \mathrm{C}_{2} \mathrm{H}_{5} ; \mathrm{R}^{\prime}=\mathrm{CH}_{3}$ reaction of sulfur nucleophiles (e.g., $\mathrm{SCOCH}_{3}^{-}, \mathrm{SCN}^{-}$, $\mathrm{S}_{2} \mathrm{O}_{3}{ }^{2-}$, etc) on the adduct 21 derived from 17 was first investigated as a route to 1-acylindoline-2-carboxylic acid derivatives having a thio function in the 2 position. The indolenine ester 17 was prepared as outlined in Chart II.

\section{Chart II}

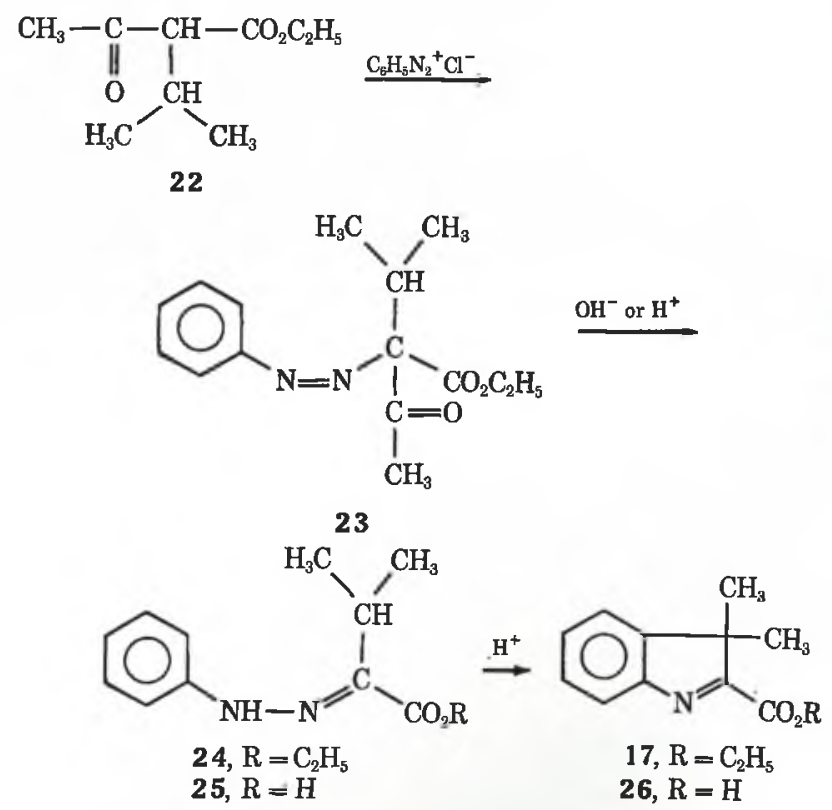

The azo ester 23, when prepared from ethyl $\alpha$-isopropylacetoacetate and benzenediazonium chloride under mildly alkaline conditions, was stable enough to permit isolation. Careful treatment with ethanolic solutions of sodium hydroxide or preferably ammonium hydroxide gave the hydrazone ester 24 , which was converted into 17 by refluxing in $\mathrm{HCl}$-saturated ethanol. The yields are much higher than reported in the published procedure ${ }^{31}$ where the coupling and hydrazone

(31) R. Robinson and H. Suginome, J. Chem. Soc., 298 (1932). 
formation steps are carried out under such strongly alkaline conditions that only the hydrazone 25 can be isolated. This, on Fischer cyclization, gives a mixture of 17 and 26 accompanied by 2,3-dimethylindole, the product of decarboxylation and rearrangement of $\mathbf{2 6}$. The indolenine 17 can also be prepared by refluxing 23 in absolute alcoholic hydrogen chloride. This indicates that the transformation $(\mathbf{2 3} \rightarrow \mathbf{2 4})$ in the JappKlingemann reaction can also be acid catalyzed.

We first examined the reaction of 17 with simple acid chlorides, such as acetyl chloride and chloroacetyl chloride, and found that when freshly purified reagents were employed, the Leuchs addition proceeded in high yield at room temperature. Interestingly, this is the first instance of addition of acyl chlorides to an indolenine-2-carboxylic acid derivative, the previous examples being limited to indolenine with 2-hydrogen, 2methyl, or 2-phenyl substituents. ${ }^{28-30}$ The indolenine 17 is less reactive than unconjugated ones, since benzoyl chloride could not be added. Reaction of 17 with ethoxycarbonyl chloride or benzyloxycarbonyl chloride was very slow, and trifluoroacetyl chloride did not react at all.

Two isomeric thioacetates, 28 and 29 , were isolated when potassium thioacetate was allowed to react with the product from acetyl chloride and $\mathbf{1 7}$ which had been allowed to warm to $40^{\circ}$, presumably as the result of a Plancher rearrangement ${ }^{32}(21 \rightarrow 27$, Chart III). With

\section{Chart III}

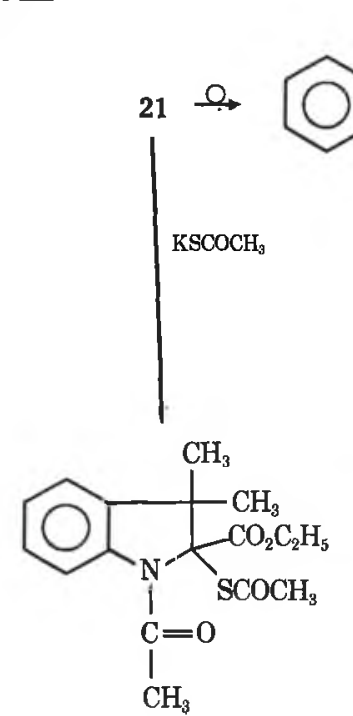

28<smiles>CCOC(=O)C1(C)N(C(C)=O)c2ccccc2C1(C)Cl</smiles><smiles>CCOC1(C)N(C(C)=O)c2ccccc2C1(C)C(C)=O</smiles>

29 potassium thiocyanate on 21, the 2-isothiocyano compound 30 (Chart IV) was isolated instead of the expected 2-thiocyano compound. ${ }^{33}$

When 21 was dissolved in ethanol, it was rapidly converted to the ethyl ether 31, a reaction analogous to the action of methanol on the reaction product from acetyl chloride and benzylidenemethylamine. ${ }^{34}$

When 32, the product from chloroacetyl chloride and 17, was allowed to react with thiourea, both chlorine atoms were displaced and a bisisothiouronium salt $\mathbf{3 3}$ resulted (Chart V). Ordinarily, chloroacetyl groups

(32) P. L. Julian, E. W. Meyer, and H. C. Printy, "Heterocyclic Compounds," Vol. 3, R. C. Elderfield, Ed., Wiley, New York, N. Y., 1952, Chapter 1.

(33) Cf. R. G. R. Bacon, "Organic Sulfur Compounds," Vol. I. N. Kharasch, Ed., Pergamon Press, New York, N. Y., 1961, p 308.

(34) H. Böhme and K. Hartke, Chem. Ber., 96, 600 (1963).
Chart IV<smiles>CCOC1(N=C=S)N(C(C)=O)c2ccccc2C1(C)C</smiles>

Chart V

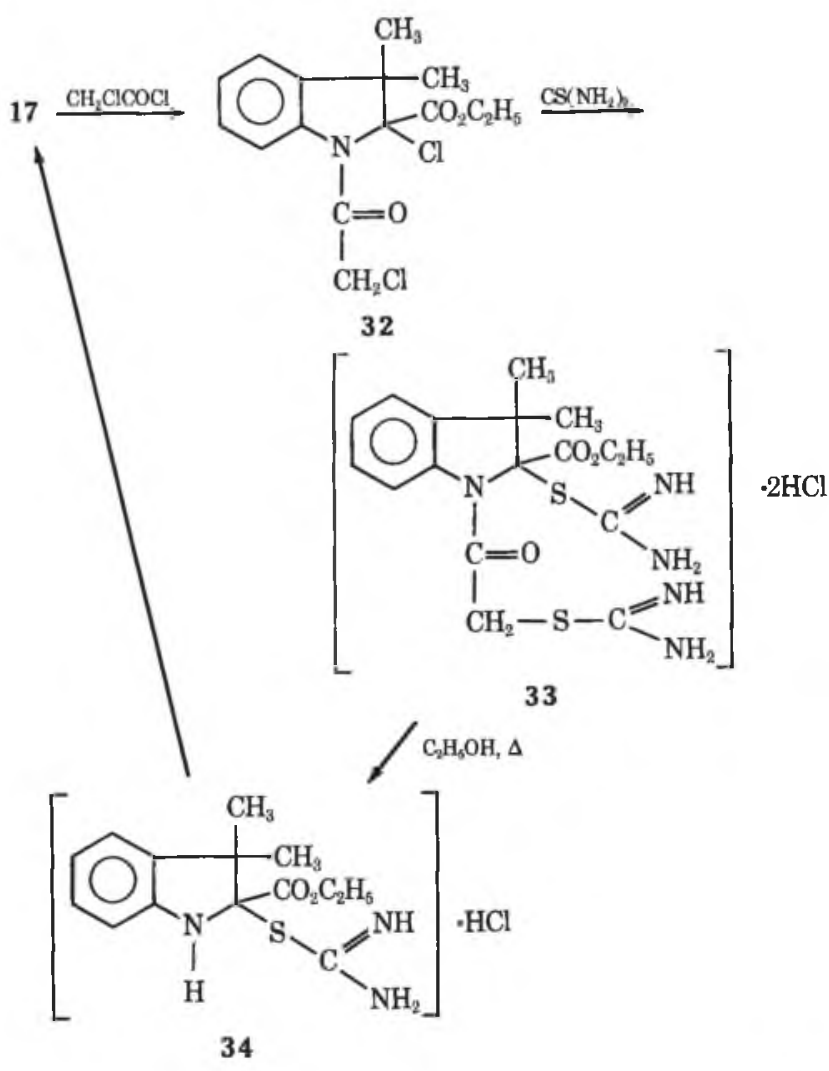

are removed by thiourea in refluxing aqueous ethanol at $\mathrm{pH} 5$ with the formation of pseudothiohydantoin. ${ }^{35,36}$ Therefore, we expected the 2-isothioureido derivative 34, but, under these conditions, isolated starting material 17.

The $\mathrm{p} K_{\mathrm{a}}$ of 33 was measured and found to be 7.7. When the solvolysis of 33 was attempted at $\mathrm{pH} 9.5$ in the hope that $\mathbf{3 4}$ might be more stable as a neutral species, still only 17 was isolated. This suggests that unacetylated indioline-2-thiols are inherently unstable. Likewise, 2-indolinols are known only as $N$-acyl or $N$ alkyl derivatives. ${ }^{32}$ At least these reactions prove that no Plancher rearrangement occurs at room temperature during acyl chloride additions or subsequent displacement reactions.

When 32 reacted with inorganic sulfides, such as ammonium sulfide, sodium mono-, di-, or tetrasulfide, or thiocarbonate, two products resulted: a mono- (37)

(35) A. Fontana and E. Scoffone, Gazz. Chim. Ital., 98, 1261 (1968). (36) W. Steglich and H. G. Batz, Angew. Chem., 83, 83 (1971). 
and a disulfide (38) in yields varying with the reactant (Chart VI). Sodium sulfide and sodium thiocarbonate

Chart VI
32<smiles>CCOC1(C(C)(C)C)N(C(C)=O)c2ccccc2C1(C)C</smiles>

35<smiles>CCOC1(C(C)(C)C)N(C(=O)CC)c2ccccc2C1(C)C</smiles>

$37, n=1$

38, $n=2$

$39, n=4$<smiles>CCOC1(S)N(C(C)=O)c2ccccc2C1(C)C</smiles>

36<smiles>CC12SSCC(=O)N(c3ccccc31)C2(C)C</smiles>

40 gave mainly the monosulfide 37 ( $c a .40 \%$ yield), whereas ammonium sulfide and sodium di- and tetrasulfide, which all exist as mixtures of mono- and polysulfides, gave the mono- and disulfide in proportions of $2: 1,1: 4$, and 2:7, respectively.

None of the thiol 36 could be detected; this together with the observation that sodium sulfide gives mainly $(>90 \%)$ the monosulfide 37 suggests that $\mathbf{3 7}$ as well as 38 arise from an intramolecular displacement of chlorine in the sulfhydryl intermediate $35(n=1$ or 2$)$ and not via the dithiol 36. A tetrasulfide 39 could not be detected although such a ring system forms easily in thio-bridged diketopiperazines. ${ }^{23}$

Models indicate that a cyclic sulfide is possible only in structures 37 and 38 . For the disulfide, but not the monosulfide, an alternate structure $\mathbf{4 0}$ may be envisaged. The disulfide 38, however, could be converted quantitatively into the monosulfide 37 with triphenylphosphine ${ }^{37}$ as evidence that no rearrangement occurred in the formation of the disulfide.

The nmr spectra of $\mathbf{3 7}$ and $\mathbf{3 8}$ show a surprisingly large difference in the $\delta$ value for the aromatic $\mathrm{C}_{7}$ proton ( $\delta 7.70$ and 8.20 , respectively), indicative of increased deshielding by the carbonyl group in 38 .

An $\mathrm{N}$-acylated 9 -amino analog of $\mathbf{3 8}$ on deacylation might undergo spontaneous ring closure and formation of the dithio-bridged diketopiperazine $41(n=2)$, an analog of dehydrogliotoxin (12b).

Accordingly, $N$-trifluoroacetylsarcosine chloride (42)<smiles>CN1C(=O)C23SC(=O)N(c4ccccc4C2(C)C)C13C</smiles>

41<smiles></smiles>

42, $\mathrm{X}=\mathrm{Y}=\mathrm{H}$

43, $\mathrm{X}=\mathrm{H} ; \mathrm{Y}=\mathrm{Cl}$

$44, \mathrm{X}=\mathrm{Y}=\mathrm{Cl}$
(37) This method has been used to convert dehydrogliotoxin $(\mathbf{1 2 b})^{9, \text { al }}$ and sporidesmin $(4)^{38}$ into monosulfides.

(38) S. Safe and A. Taylor, J. Chem. Soc. C, 1189 (1971). was prepared from the free acid with thionyl chloride, ${ }^{39}$ conditions mild enough not to affect the trifluoroacetyl group. ${ }^{40}$ When 42 was refluxed in sulfuryl chloride in an attempt to prepare 43 , the $\alpha$-dichloro acid chloride 44 was isolated. Details on this synthesis as well as some reactions of this interesting compound have been reported elsewhere. ${ }^{41}$

When the addition product from 44 and 17 was allowed to react with sodium tetrasulfide, a ninhydrin-positive, crystalline compound was isolated in $30 \%$ yield whose structure agrees with $\mathbf{4 9}$ (Chart VII).

Chart VII

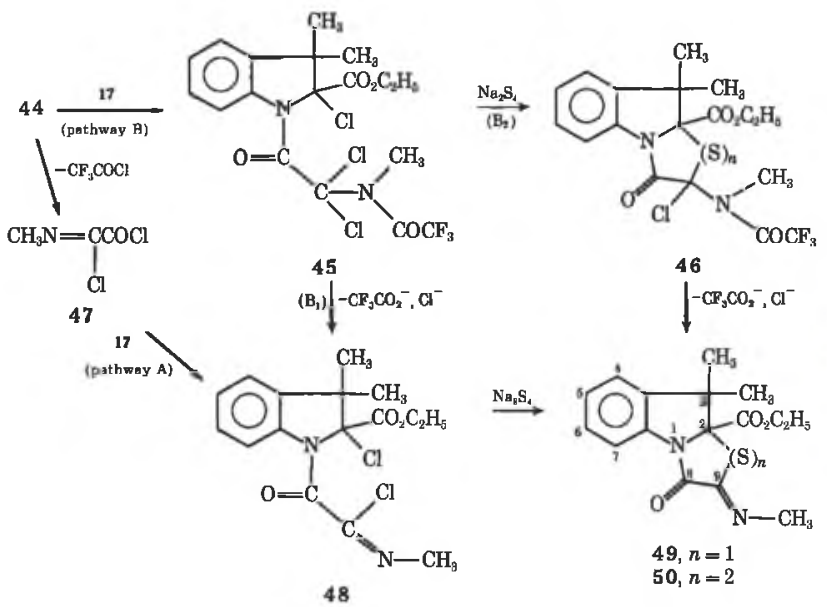

As we have proposed elsewhere ${ }^{41} 44$ may decompose spontaneously to form 47 , which may then react with 17 to give $\mathbf{4 8}$ which in turn forms $\mathbf{4 9}$ with polysulfide ions in an intramolecular reaction (pathway A). Alternatively, pathway $B$ proceeds via 45 , the addition product of 44 and 17, which may then react in either or both of two ways: base-catalyzed hydrolysis of the $N$-trifluoroacetyl group to yield 49 via 48 (pathway $B_{1}$ ) or removal of the $N$-trifluoroacetyl group following reaction with polysulfide ions (pathway $B_{2}$ ). At the moment, we lack the definitive evidence necessary for a decision among these mechanistic possibilities.

We were unable to detect the disulfide $\mathbf{5 0}$, possibly because it is either inherently unstable, or unable to survive the strongly alkaline conditions of the tetrasulfide reaction. ${ }^{42}$

The monosulfide 49 was reduced with sodium cyanoborohydride $4 \mathbf{4}$ to the amines 51 and 52 (Chart VIII), which are secogliotoxin analogs.

The course of the reduction is guided by steric induction of the carbethoxy group. The nmr spectrum of the reduction mixture showed two signals for the $\mathrm{C}_{9}$ proton, at $\delta 5.65$ and 5.29 in the ratio $2: 1$, respectively, and two signals at $\delta 2.54$ with a separation of $2 \mathrm{~Hz}$ for the $N$ methyl group. It is assumed that the $\mathrm{C}_{\theta}$ proton in the stereoisomer $\mathbf{5 2}$ is more shielded than in $\mathbf{5 1}$, so that the signals at $\delta 5.65$ and 5.29 can be assigned to structures $\mathbf{5 1}$ and 52, respectively, of which $\mathbf{5 1}$ is the major (66\%) and the diastereomer 52 the minor product (33\%). An

(39) E. Schwenk and D. Papa, J. Amer. Chem. Soc., 70, 3626 (1948).

(40) F. Weygand, and U. Glockler, Chem. Ber., 89, 653 (1956).

(41) H. C. J. Ottenheym, T. F. Spande, and B. Witkop, J. Org. Chem., 37, 3358 (1972)

(42) The alkaline decomposition of organic disulfides very often produces monosulfides. ${ }^{43}$

(43) J. P. Danehy, Int. J. Sulfur Chem., Part B, 6, 103 (1971).

(44) R. F. Borch, M. D. Bernstein, and D. Durst, J. Amer. Chem. Soc,, 93, 2897 (1971). 
Chart VIII

$49 \underset{\mathrm{pH} 3.2}{\stackrel{\mathrm{NaBH}_{9} \mathrm{CN}}{\longrightarrow}}$<smiles>CCOC(=O)[C@@]12SCC(=O)N1c1ccccc1C2(C)C</smiles><smiles>CCOC(=O)N[C@H]1S[C@]2(C(=O)NC)N(C1=O)c1ccccc1C2(C)C</smiles>

epithiodiketopiperazine can be formed only from 51 in which ester and amine functions are in a cis relationship. A bulkier hydride donor might make the reduction even more stereoselective.

Surprisingly the conversion of 49 into 51 and 52 led to no change in the ir spectrum of the amide carbonyl absorption $\left(1705 \mathrm{~cm}^{-1}\right)$. This suggests that conjugation in $\mathrm{O}=\mathrm{CC}=\mathrm{NCH}_{3}$ has little effect.

The mixture of monosulfides 51 and 52 was heated 1 ethanol in an attempt to form the epimonothiodiketopiperazine $41(n=1)$. Only in a sealed tube at $125^{\circ}$ did a reaction occur yielding, besides starting material, a compound with a slightly higher $R_{\mathrm{f}}$ value on tlc. ${ }^{45}$ This compound had nearly the same mass spectrum as the starting mixture, with differences only in peak intensities, indicative of closely related isomers of 51 and/or 52. The nmr spectrum could best be interpreted as a mixture of structures 55 and 56 (Chart IX),

Chart IX

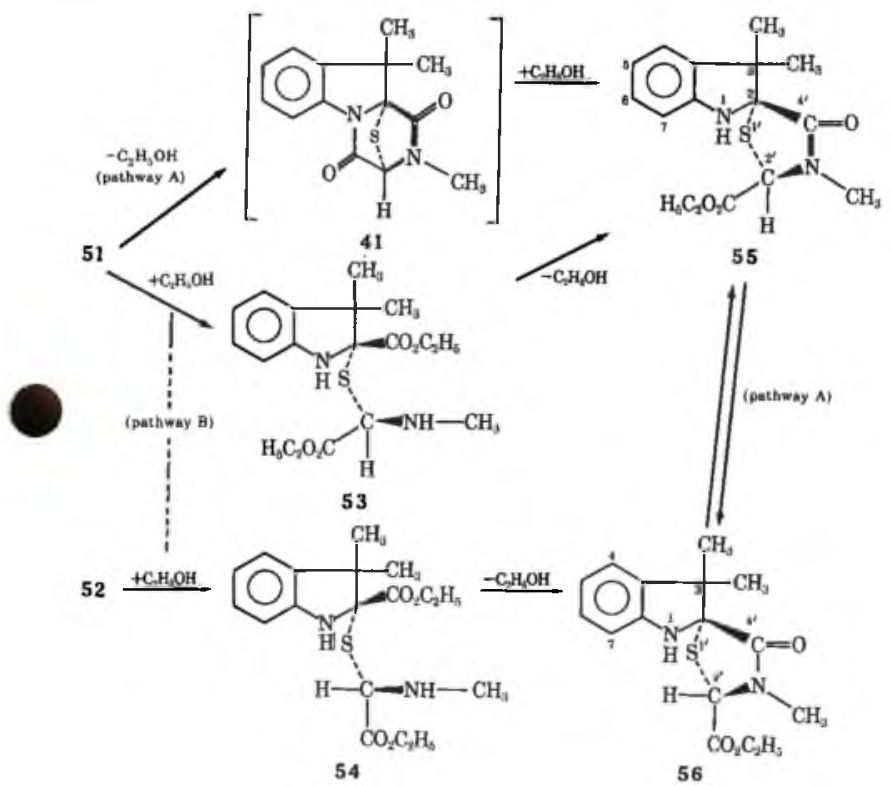

compounds derived from the starting material by an interesting translactamization.

The two signals assigned to the $N$-methyl groups were shifted downfield ( $\delta 3.23$ and 3.13 ) and show a larger difference in chemical shifts than in 51 and $52(\Delta \delta=5$ and $2 \mathrm{~Hz}$, respectively). Surprisingly only one broad signal was observable for the $\mathrm{C}_{2}$ ' proton. Therefore, the possibility that we had in hand only one pair of enantiomers, $\mathbf{5 5}$ or 56, had also to be considered; the two signals for the $N$-methyl group could be explained by a conformational or long-range coupling effect.

(45) Under these conditions compound 37 was found to be stable.
However, nmr spectra at -20 or $-40^{\circ}$ and irradiation of the $C_{2}{ }^{\prime}$ proton failed to change the relative intensities of the two $N$-methyl signals and indicated that the isolated material was most likely a mixture of two pairs of enantiomers, 55 and 56. An $\mathrm{nmr}$ of the recovered starting material mixture indicated that the proportion of $\mathbf{5 2}$ in the mixture had increased greatly and was now twice that of 51.

Particular attention was given to these considerations, for if only one pair of enantiomers had been formed, this probably would have been 55, derived only from the reactive starting material 51 , via the desired diketopiperazine 41 (pathway A, Chart IX). A Dreiding model shows that the epimonothiodiketopiperazine ring system in $\mathbf{4 1}$ is a highly strained though not an impossible one as has been shown by Taylor. ${ }^{9,38}$ The occurrence of two pairs of enantiomers could then be explained by epimerization at $\mathrm{C}_{2}{ }^{\prime}$ in 55 . A deuterium-exchange study is planned to check this possibility.

The occurrence of $\mathbf{5 5}$ and $\mathbf{5 6}$ would also be explained by pathway B, Chart IX. If the amide groups in $\mathbf{5 1}$ and 52 were cleaved by ethanol, the $\alpha$-thio-bridged $\alpha$ amino acid esters 53 and 54 would result. These could lactamize in two ways, yielding besides the starting materials the structures 55 and 56, respectively. Structures 53 and 54 with an unacylated $\alpha$-thio amino acid moiety are undoubtedly unstable ${ }^{46}$ (see also Chart V and accompanying text), and should break down to the indolenine ester 17. However, the reaction mixture $51+52 \rightleftarrows 55+56$ showed only two spots on tlc with no trace of side products, ${ }^{47}$ making this mechanism unlikely.
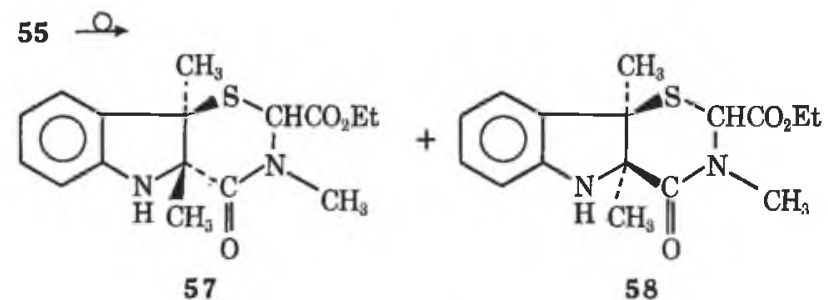

Milder reaction temperatures and the use of nonprotic solvents provided no new information. At $90^{\circ}$ the formation of the new isomers is very slow and no new component could be detected; diglyme as solvent at 90 or $120^{\circ}$ failed to give any identifiable product. At present there is no evidence permitting a choice between pathways $\mathbf{A}$ and $\mathbf{B}$.

\section{Experimental Section}

Infrared spectra were measured with Perkin-Elmer spectrophotometers, Models 237B $\left(\mathrm{CHCl}_{3}\right.$ or $\left.\mathrm{CCl}_{4}\right)$ and $421(\mathrm{KBr})$, and uv spectra with a Cary Model $11(95 \% \mathrm{EtOH})$. Mass spectra were obtained with the double-focusing Hitachi RMU-6E mass spectrometer. Proton magnetic resonance spectra were measured on the Varian Associates Model A-60 spectrometer. Chemical shifts are reported as $\delta$ values (ppm) relative to tetramethylsilane as an internal standard; deuteriochloroform was used as solvent unless stated

(46) Pojer and Rae ${ }^{27}$ described the synthesis of 13 and 2,2'-dibenzamido-2,2'-dithiodipropanoic acid, in which the amino function is acylated. Interestingly, the deacylated products were not mentioned.

(47) A Plancher rearrangement ${ }^{32}$ producing 57 and 58 cannot be completely ruled out. The shift in amide carbonyl absorption from 1690 to $1640 \mathrm{~cm}^{-1}$ which accompanies this reaction is somewhat unexpected. Although the latter absorption is normal for a tertiary amide, it could also indicate that the amide is part of a six-membered ring. Arguing against this possibility, however, is the similarity of the 3 methyl signals in the nmr spectra of starting materials and products. 
otherwise. Melting points were taken on a Kofler hot stage and are corrected. Thin layer chromatography (tlc) was carried out using Merck precoated silica gel F-254 plates (thickness: $0.25 \mathrm{~mm}$ for analytical, $2.0 \mathrm{~mm}$ for preparative); spots were visualized with a uv hand lamp, iodine vapor, or a $0.1 \%$ solution of ninhydrin in methanol-1-butanol- $2 N$ acetic acid $(20: 10: 1 \mathrm{v} / \mathrm{v})$.

Ethyl $\alpha$-Isopropylacetoacetate (22). This compound was prepared from ethyl acetoacetate and 2-bromopropane following the procedure for the synthesis of ethyl $n$-propylacetoacetate. ${ }^{4 B}$ Vacuum distillation ( $34 \mathrm{~mm}$ ) on a Vigreux column yielded two fractions, bp $83-105^{\circ}$ and $105-108^{\circ}$, the latter being the desired compound, the former being the $\mathrm{O}$-alkylated product. ${ }^{49}$ When freshly distilled ethyl acetoacetate was used, only the desired 22 resulted in $40 \%$ yield: $\operatorname{nmr} \delta 4.14\left(\mathrm{q}, 2 \mathrm{H}, \mathrm{CH}_{2} \mathrm{CH}_{3}\right), 3.22(\mathrm{~d}, 1 \mathrm{H}, \mathrm{COCHCO}, J=$ $9 \mathrm{~Hz}$ ), 2.40 (mult, $1 \mathrm{H}, \mathrm{CH}_{2} \mathrm{CHCH}_{3}$ ), 2.15 (s, $3 \mathrm{H}, \mathrm{CH}_{3} \mathrm{CO}$ ), 1.21 (t, $\left.3 \mathrm{H}, \mathrm{CH}_{2} \mathrm{CH}_{3}\right), 0.9\left(2 \mathrm{~d}, 6 \mathrm{H}, \mathrm{CH}_{3} \mathrm{CHCH}_{3}, J=6 \mathrm{~Hz}\right.$, spacing $2 \mathrm{~Hz}$ ). O-Alkylated product: $\delta 4.12\left(\mathrm{q}, 2 \mathrm{H}, \mathrm{CH}_{2} \mathrm{CH}_{3}\right), 3.45(\mathrm{~s}, 1 \mathrm{H}, \mathrm{C}=$ $\mathrm{CH}), 2.18\left(\mathrm{~s}, 3 \mathrm{H}, \mathrm{CH}_{3} \mathrm{C}=\mathrm{C}\right), 1.21\left(\mathrm{t}, 3 \mathrm{H}, \mathrm{CH}_{2} \mathrm{CH}_{3}\right), 0.90(2 \mathrm{~d}, 6 \mathrm{H}$, $\mathrm{CH}_{3} \mathrm{CHCH}_{3}, J=6 \mathrm{~Hz}$, spacing $2 \mathrm{~Hz}$ ).

Ethyl $\alpha$-Phenylazo- $\alpha$-isopropylacetoacetate (23). Solution A. A solution of $51.0 \mathrm{~g}(0.30 \mathrm{~mol})$ of ethyl isopropylacetoacetate (22) in $200 \mathrm{ml}$ of ethanol was cooled at $-15^{\circ}$ (ice-salt bath). Just before the addition of solution B to A, $232.5 \mathrm{ml}$ of $5 \mathrm{~N} \mathrm{NaOH}(1.15 \mathrm{~mol})$, cooled to $-15^{\circ}$, was added at once.

Solution B. A solution of benzenediazonium chloride was prepared from $27.9 \mathrm{~g}(0.30 \mathrm{~mol})$ of freshly distilled aniline, $255 \mathrm{ml}$ (1.02 mol) of $4 \mathrm{~N} \mathrm{HCl}$, and $21.0 \mathrm{~g}(0.30 \mathrm{~mol})$ of sodium nitrite dissolved in $50 \mathrm{ml}$ of water. All solutions were cooled at $-15^{\circ}$. Immediately after the addition of the sodium nitrite solution, solution $B$ was added with swirling to solution $A$ and cooled in a Dry Ice-acetone bath. After the solution was stirred for $45 \mathrm{~min}$ at $-15^{\circ}$, an oil separated from the dark red colored reaction mixture. After acidification with $2 \mathrm{~N} \mathrm{HCl}$, this oil was extracted with ether. The organic layer was washed with water, $5 \% \mathrm{Na}$ $\mathrm{HCO}_{3}$, and finally water until neutral, dried $\left(\mathrm{Na}_{2} \mathrm{SO}_{4}\right)$, and filtered, and the ether was removed to yield a dark red residue. From this oil, $16.7 \mathrm{~g}(0.098 \mathrm{~mol})$ of unreacted 22 could be isolated by vacuum distillation (bp $\left.48-52^{\circ}(0.5 \mathrm{~mm})\right)$. The dark red residue $(48.0 \mathrm{~g}$, $0.175 \mathrm{~mol}, 87 \%$ based upon recovered starting material) was stored at room temperature: $\mathrm{nmr}, \delta 7.5$ (mult, $\left.5 \mathrm{H}, \mathrm{C}_{6} \mathrm{H}_{5}\right), 4.28(\mathrm{q}, 2 \mathrm{H}$, $\mathrm{CH}_{2} \mathrm{CH}_{3}$ ), 2.75 (mult, $1 \mathrm{H}, \mathrm{CH}_{3} \mathrm{CHCH}_{3}$ ), 2.17 (s, $3 \mathrm{H}, \mathrm{CH}_{3} \mathrm{CO}$ ), $1.28\left(\mathrm{t}, 3 \mathrm{H}, \mathrm{CH}_{2} \mathrm{CH}_{3}\right.$ ), 1.10 (d, $6 \mathrm{H}, \mathrm{CH}_{3} \mathrm{CHCH}_{3}$ ); uv $\lambda_{\max }{ }^{\mathrm{EtOH}} 277$ $\mathrm{nm}$ (shoulders at 215 and $330 \mathrm{~nm}$ ).

Ethyl $\alpha$-Keto- $\beta$-methylbutyrate Phenylhydrazone (24). To a solution of $48.0 \mathrm{~g}(0.175 \mathrm{~mol})$ of the azo compound 23 in $250 \mathrm{ml}$ of ethanol was added $50 \mathrm{ml}$ of concentrated aqueous $\mathrm{NH}_{4} \mathrm{OH}$. The mixture was stirred and kept at $50^{\circ}$ while the reaction was monitored by uv spectroscopy (shift from $\lambda_{\max } 277$ to $325 \mathrm{~nm}$ ). The reaction was stopped after the starting material had disappeared (45 min). The volume was reduced until $c a .100 \mathrm{ml}$, water was added, and the dark red solution was extracted with ether after acidification with 6 $N \mathrm{HCl}$. The organic layer was washed with water until neutral and dried $\left(\mathrm{Na}_{2} \mathrm{SO}_{4}\right)$, and the ether was removed to yield $38.5 \mathrm{~g}(0.163 \mathrm{~mol}$, $93 \%$ ) of a dark red solid, which was used without further purification in the next step: uv $\lambda_{\max } \mathrm{EtOH} 323 \mathrm{~nm}$, shoulder at $292 \mathrm{~nm} ; \mathrm{nmr} \delta$ 7.18 (broad mult, $6 \mathrm{H}, \mathrm{C}_{6} \mathrm{H}_{5}+\mathrm{NH}$ ), $4.26\left(\mathrm{q}, 2 \mathrm{H}, \mathrm{CH}_{2} \mathrm{CH}_{3}\right), 3.02$ (heptet, $1 \mathrm{H}, \mathrm{CH}$ ), 1.35 (t, $3 \mathrm{H}, \mathrm{CH}_{2} \mathrm{CH}_{3}$ ), 1.27 (d, $6 \mathrm{H}, \mathrm{CH}_{3} \mathrm{CHCH}_{3}$ ).

A small sample was purified by vacuum sublimation at $90^{\circ}(0.75$ $\mathrm{mm}$ ), followed by crystallization from hexane and washing with petroleum ether, to give thin needles, mp 100.5-101.5 ${ }^{\circ}$; mass spectrum $\left(175^{\circ}\right)$ m/e $234\left(\mathrm{M}^{+}\right), 219\left(\mathrm{M}^{+}-\mathrm{CH}_{3}\right), 199,191\left(\mathrm{M}^{+}-\right.$ $\left.\mathrm{C}_{3} \mathrm{H}_{7}\right), 189\left(\mathrm{M}^{+}-\mathrm{OC}_{2} \mathrm{H}_{5}\right), 160\left(\mathrm{M}^{+}-1-\mathrm{CO}_{2}-\mathrm{C}_{2} \mathrm{H}_{5}\right), 145(160$ $-\mathrm{CH}_{3}$ ), 105, 92 (aniline -1 )

$\alpha$-Keto- $\beta$-methylbutyric Acid Phenylhydrazone (25). This compound was prepared ${ }^{31}$ in $20 \%$ yield and showed on tlc (3\% acetic acid-benzene) only one spot: uv $\lambda_{\max }{ }^{\mathrm{EtOH}} 341 \mathrm{~nm}$, shoulders at $297,288 \mathrm{~nm}$; nmr $\delta 7.3$ (mult, $6 \mathrm{H}, \mathrm{C}_{6} \mathrm{H}_{5}+\mathrm{NH}$ ), 3.08 (heptet, $1 \mathrm{H}$, $\left.\mathrm{CH}_{3} \mathrm{CHCH}_{8}, J=7.5 \mathrm{~Hz}\right), 1.22\left(\mathrm{~d}, 6 \mathrm{H}, \mathrm{CH}_{3} \mathrm{CHCH}_{3}\right)$. Other properties agreed well with reported values.

Ethyl 3,3-Dimethylindolenine-2-carboxylate (17). An ice-cooled solution of $12.0 \mathrm{~g}(51 \mathrm{mmol})$ of the crude hydrazone ester 24 in $100 \mathrm{ml}$ of absolute ethanol was saturated with dry $\mathrm{HCl}$ (solution changes from dark brown to violet in color) and then refluxed for 9 min during which time ammonium chloride precipitated. The ethanol was removed and the residue extracted with ether and $5 \%$

(48) A. I. Vogel, "A Textbook of Practical Organic Chemistry," 3rd ed, Longmans, Green and Co., New York, N. Y., 1957, p 481.

(49) S. T. Yoffe, E. I. Fedin, P. V. Petrovskii, and M. I. Kabachnik, Tetrahedron Lett., 2661 (1966).
$\mathrm{Na}_{2} \mathrm{CO}_{3}$. The aqueous layer did not contain any free acid 26. The organic layer was washed with water until neutral and dried $\left(\mathrm{Na}_{2} \mathrm{SO}_{4}\right)$ and the ether removed to yield $10.4 \mathrm{~g}$ (48 mmol, 94\%) of a dark brown solid, which was purified by vacuum sublimation at $90^{\circ}(1.0$ $\mathrm{mm})$, followed by recrystallization from petroleum ether $\left(80-100^{\circ}\right)$ at $-20^{\circ}$. Large colorless needles with $\mathrm{mp} 78-79^{\circ}$ (lit. ${ }^{31} \mathrm{mp} 79$ $80^{\circ}$ ) were obtained in $52 \%$ yield: tlc ( $2 \%$ ethanol benzene) one spot; uv $\lambda_{\max }{ }^{\mathrm{E} \text { tOH }} 294$ and $232 \mathrm{~nm}$ (equal intensities); ir (KBr) 3070, $3050,2980,2950,2870,1713$ (CO) $1542,1460,1365,1335,1310$, $1280,1210,1190,1120,1090,1065,1010,860,785,770$, and 750 $\mathrm{cm}^{-1}$; nmr $\delta 7.8$ (mult, $1 \mathrm{H}, \mathrm{C}_{7}-\mathrm{H}$ ), 7.35 (mult, $3 \mathrm{H}, \mathrm{C}_{4-\sigma} \mathrm{H}$ ), 4.46 (q, $\left.2 \mathrm{H}, \mathrm{CH}_{2} \mathrm{CH}_{3}\right), 1.52$ (s, 6H, $\left.\mathrm{CH}_{3} \mathrm{CCH}_{3}\right), 1.43$ (t, $3 \mathrm{H}, \mathrm{CH}_{2} \mathrm{CH}_{3}$ ); mass spectrum $\left(175^{\circ}\right), \mathrm{m} / \mathrm{e} 217\left(\mathrm{M}^{+}\right), 202\left(\mathrm{M}^{+}-\mathrm{CH}_{\mathrm{s}}\right), 188,173,172$ $\left(\mathrm{M}^{+}-\mathrm{OC}_{2} \mathrm{H}_{5}\right), 158,145,144\left(\mathrm{M}^{+}-\mathrm{CO}, \mathrm{C}_{2} \mathrm{H}_{4}\right), 143,130,128,117$, $115,103,91,77$.

The ester 17 was also prepared according to Robinson and Suginome $^{31}$ from the hydrazone acid 25 , yielding $6.5 \%$ of the ester 17 and $35.5 \%$ of the acid 26.

A $2.0-\mathrm{g}$ sample of the azo ester 23 was converted into 17 in $48 \%$ yield by the treatment given to the hydrazone ester 24 mentioned above. Both procedures led to material which was found to be identical in all respects with the specimen previously obtained.

Ethyl 1-Acetyl-2-thioacetyl-3,3-dimethylindoline-2-carboxylate and Isomer (28 and 29). A solution of $17(434 \mathrm{mg}, 2 \mathrm{mmol})$ in $4 \mathrm{ml}$ of freshly distilled acetyl chloride was kept at $40^{\circ}$ for $15 \mathrm{hr}$, during which time the reaction was monitored by tlc ( $4 \%$ ethanol-benzene). After addition of $5 \mathrm{ml}$ of benzene, solvent and excess reagent werd removed under vacuum and exclusion of moisture. Tlc $(4 \%$ ethanol-benzene) showed two spots with $R_{\mathrm{f}}$ values smaller than the starting material: ir $\left(\mathrm{CHCl}_{3}\right) 1750,1690 \mathrm{~cm}^{-1}$, disappearance of $1713 \mathrm{~cm}^{-1}$; uv $\lambda_{\text {max }}{ }^{\text {EtOH }} 248 \mathrm{~nm}$, shoulders at 278 and $286 \mathrm{~nm}$ (spectrum is actually of the ether 31). To the light brown oil was added an alcoholic solution of $570 \mathrm{mg}(5 \mathrm{mmol})$ of potassium thioacetate after which potassium chloride separated. Stirring was continued for $2 \mathrm{hr}$; the alcohol was removed and the residue extracted with ether. The ether layer was washed with $5 \% \mathrm{NaHCO}_{3}$ and water until neutral and dried $\left(\mathrm{Na}_{2} \mathrm{SO}_{4}\right)$, and the ether was removed to yield $545 \mathrm{mg}$ of a yellow oil: tlc (4\% ethanol-benzene) besides starting material, two spots with lower $\boldsymbol{R}_{\boldsymbol{f}}$. The oil was chromatographed on a silica gel column $(100 \mathrm{~g})$ with $4 \%$ ethanol-benzene, yielding three fractions: the first fraction appeared to be starting material $17(30 \mathrm{mg})$, the second and third were assigned structures 29 and 28 , respectively, on the following basis. Ir, identical for both fractions $\left(\mathrm{CHCl}_{3}\right) 1750$ (broad ester) and $1680 \mathrm{~cm}^{-1}$ (broad $\mathrm{CON}+\mathrm{COS}$ ). Fraction 2: $\mathrm{nmr} \delta 7.4-7.0$ (mult, $4 \mathrm{H}, \mathrm{C}_{6} \mathrm{H}_{4}$ ), 4.30 (q, $2 \mathrm{H}, \mathrm{CH}_{2} \mathrm{CH}_{3}$ ), 2.48 (s, $3 \mathrm{H}, \mathrm{CH}_{3} \mathrm{CON}$ ), 2.32 (s, $3 \mathrm{H}, \mathrm{CH}_{3} \mathrm{COS}$ ), $1.47\left(\mathrm{~s}, 3 \mathrm{H}, \mathrm{C}_{3} \mathrm{C}_{\alpha} \mathrm{H}_{3}\right), 1.37\left(\mathrm{~s}, 3 \mathrm{H}, \mathrm{C}_{3} \mathrm{C}_{\beta} \mathrm{H}_{3}\right), 1.20\left(\mathrm{t}, 3 \mathrm{H}, \mathrm{CH}_{2} \mathrm{CH}_{3}\right)$ mass spectrum $\left(190^{\circ}\right) \mathrm{m} / \mathrm{e} 335\left(\mathrm{M}^{+}\right), 305\left(\mathrm{M}^{+}-\mathrm{C}_{2} \mathrm{H}_{6}\right), 293\left(\mathrm{M}^{+}-\right.$ $\left.\mathrm{CH}_{3} \mathrm{CO}\right), 260\left(\mathrm{M}^{+}-\mathrm{CH}_{3} \mathrm{COS}\right), 217\left(\mathrm{M}^{+}-\mathrm{CH}_{3} \mathrm{CO}-\mathrm{CH}_{3} \mathrm{COS}\right)$. Fraction 3: nmr $\delta 7.40-7.0$ (mult, $4 \mathrm{H}, \mathrm{C}_{6} \mathrm{H}_{4}$ ), 4.25 (q, $2 \mathrm{H}, \mathrm{CH}_{2-}$ $\mathrm{CH}_{3}$ ), 2.48 (s, $3 \mathrm{H}, \mathrm{CH}_{3} \mathrm{CON}$ ), 2.18 (s, $3 \mathrm{H}, \mathrm{CH}_{3} \mathrm{COS}$ ), 1.60 (s, $3 \mathrm{H}$, $\left.\mathrm{C}_{3}-\mathrm{C}_{\alpha} \mathrm{H}_{3}\right), 1.28\left(\mathrm{~s}, 3 \mathrm{H}, \mathrm{C}_{2} \mathrm{C}_{\beta} \mathrm{H}_{3}\right), 1.20\left(\mathrm{t}, 3 \mathrm{H}, \mathrm{CH}_{2} \mathrm{CH}_{3}\right)$; mass spectrum, nearly identical with that of fraction 2 . When the reaction of the acid chloride and 17 was carried out at room temperature, only one spot was observed in tlc, which had the same $R_{\mathrm{f}}$ value as fraction 3 .

Ethyl 1-Acetyl-2-isothiocyano-3,3-dimethylindoline-2-carboxylate (30). A solution of 17 (10 $\mathrm{mg}, 0.46 \mathrm{mmol})$ in $2 \mathrm{ml}$ of dry benzene was allowed to react with acetyl chloride $(50 \mathrm{mg}$ ) and stirred at room temperature for $15 \mathrm{hr}$. After that time no starting material could be detected on tlc ( $4 \%$ ethanol-benzene, $R_{f} 0.24$ ). The solvent and excess acetyl chloride were removed in vacuo with exclusion of moisture. To the light brown oil was added with stirring an alcoholic solution of $40 \mathrm{mg}$ of potassium thiocyanate after which potassium chloride separated. Stirring was continued for $15 \mathrm{~min}$, the solvent removed, and the residue extracted with water-ether. The ether layer was washed twice with water and dried $\left(\mathrm{Na}_{2} \mathrm{SO}_{4}\right)$, and the solvent was removed to yield $12 \mathrm{mg}(0.38 \mathrm{mmol}, 83 \%)$ of a light yellow oil: tlc (4\% ethanol-benzene) showed only one spot, $R_{f}$ 0.45; ir $\left(\mathrm{CHCl}_{3}\right) 2980$ (broad), 2040 (strong, broad, $-\mathrm{N}=\mathrm{C}=\mathrm{S}^{33}$ ), 1760 (ester), $1680 \mathrm{~cm}^{-1}\left(\mathrm{CH}_{3} \mathrm{CON}\right)$; mass spectrum $\left(150^{\circ}\right) \mathrm{m} / \mathrm{e} 318$ $\left(\mathrm{M}^{+}\right), 305,278,260\left(\mathrm{M}^{+}-\mathrm{NCS}\right), 244,232,217$.

Ethyl 1-Acetyl-2-ethoxy-3,3-dimethylindoline-2-carboxylate (31). The addition product 21 of $434 \mathrm{mg}(2 \mathrm{mmol})$ of 17 and $3.4 \mathrm{~g}$ (43 mmol) of acetyl chloride was prepared as described above for the preparation of 30 . To the light brown oil was added $5 \mathrm{ml}$ of absolute ethanol; the solution was stirred for $2 \mathrm{hr}$ at room temperature after which excess reagent was removed, yielding $470 \mathrm{mg}$ of a yellow oil: tlc (4\% ethanol-benzene) showed only one spot, $\boldsymbol{R}_{\mathrm{f}}$ 0.20 ; nmr $\delta 7.8$ (mult, $1 \mathrm{H}, \mathrm{C}_{7}-\mathrm{H}$ ), 7.4-7.0 (mult, $3 \mathrm{H}, \mathrm{C}_{4-6}-\mathrm{H}$ ), 4.30 
(q, $2 \mathrm{H}, \mathrm{COOCH}_{2}-$ ), 3.30 (q, $2 \mathrm{H}, \mathrm{COCH}_{2}-$ ), 2.35 (s, $3 \mathrm{H}, \mathrm{CH}_{3} \mathrm{CON}$ ), $1.45\left(\mathrm{~s}, 6 \mathrm{H}, \mathrm{CH}_{3} \mathrm{CCH}_{3}\right), 1.32\left(\mathrm{t}, 3 \mathrm{H},-\mathrm{COOCH}_{2} \mathrm{CH}_{3}\right), 1.13(\mathrm{t}, 3 \mathrm{H}$, $\left.\mathrm{COCH}_{2} \mathrm{CH}_{3}\right)$; mass spectrum $\left(160^{\circ}\right)$ m/e $305\left(\mathrm{M}^{+}\right), 275\left(\mathrm{M}^{+}-\right.$ $\left.\mathrm{C}_{2} \mathrm{H}_{6}\right), 232\left(275-\mathrm{CH}_{3} \mathrm{CO}\right), 218,217$, etc.

2.9-Bisisothiouromium-1-acetyl-2-carbethoxy-3,3-dimethylindoline Dichloride (33). The addition product of $17(434 \mathrm{mg}, 2 \mathrm{mmol})$ and $3.3 \mathrm{~g} \mathrm{(26} \mathrm{mmol)} \mathrm{of} \alpha$-chloroacetyl chloride in $3 \mathrm{ml}$ of dry benzene was prepared as described for the preparation of 30 (stirred for $15 \mathrm{hr}$ ). To the light yellow oil was added under stirring a solution of $381 \mathrm{mg}$ ( $5 \mathrm{mmol}$ ) of thiourea in $10 \mathrm{ml}$ of 2-propanol. Stirring was continued for $15 \mathrm{~min}$, after which the clear solution was refluxed for $1 \mathrm{hr}$. Within a few minutes a precipitate formed. The reaction mixture was then cooled in ice, the precipitate filtered off, and from the filtrate the solvent removed to yield $950 \mathrm{mg}$ of a yellow powder: uv $\lambda_{\max }{ }^{E \text { tOH }} 247 \mathrm{~nm}$ (shoulders at 278 and $286 \mathrm{~nm}$ ); $\mathrm{p} K_{\mathrm{a}}=7.7 ; \mathrm{nmr}$ $\delta 7.67$ (mult, $1 \mathrm{H}, \mathrm{C}_{7}-\mathrm{H}$ ), 7.48 (mult, $3 \mathrm{H}, \mathrm{C}_{4-6}-\mathrm{H}$ ), 4.44 (q, $2 \mathrm{H}$, $\mathrm{CH}_{2} \mathrm{CH}_{3}$ ), 3.31 (s, $2 \mathrm{H},-\mathrm{COCH}_{2} \mathrm{~S}-$ ), 1.50 (s, $\left.6 \mathrm{H}, \mathrm{CH}_{3} \mathrm{CCH}_{3}\right), 1.42$ (t, $3 \mathrm{H},-\mathrm{CH}_{2} \mathrm{CH}_{3}$ ).

Conversion of 33 into 17 . The yellow powder $(100 \mathrm{mg})$ was dissolved in $10 \mathrm{ml}$ of $40 \%$ ethanol; the $\mathrm{pH}$ of this solution was adjusted at 5.2 or in another experiment to 9.5 with $0.5 \mathrm{M}$ sodium acetate and $5 \% \mathrm{NaHCO}_{3}$, respectively. The reaction mixtures were refluxed for $5 \mathrm{~min}$, then the volume was reduced to $5 \mathrm{ml}$, and the mixtures were extracted with ethyl acetate. The organic layers were dried $\left(\mathrm{Na}_{2} \mathrm{SO}_{4}\right)$ and the solvent was removed, yielding 27 and $28 \mathrm{mg}$ ( $59 \%$ and $60 \%$, respectively) of crystalline material having $\boldsymbol{R}_{\mathrm{f}}$ values, uv, and ir spectra identical with those of 17.

2-Carbethoxy-3,3-dimethylindolino[2,1- $b]$ thiazolidinone-8 (37 and 38). ${ }^{\mathrm{s0}}$ The addition product 32 of $1.085 \mathrm{~g}(5 \mathrm{mmol})$ of 17 and $6.0 \mathrm{~g}$ $(40.7 \mathrm{mmol}$ ) of freshly distilled $\alpha$-chloroacetyl chloride in $10 \mathrm{ml}$ of dry benzene was prepared as described for the preparation of 30 (stirred for $15 \mathrm{hr}$ ). A solution of the light yellow oil in $25 \mathrm{ml}$ of dry diglyme was divided into five 5-ml aliquots. To the first sample was added quickly with ice cooling $20 \mathrm{ml}$ of a freshly prepared, icecold solution of sodium disulfide $(1.1 \mathrm{M})$ in water. The latter was prepared the following way: $3.4 \mathrm{~g}(0.11 \mathrm{~mol})$ of powdered sulfur was dissolved in a solution of $26 \mathrm{~g}(0.11 \mathrm{~mol})$ of $\mathrm{Na}_{2} \mathrm{~S} \cdot 9 \mathrm{H}_{2} \mathrm{O}$ in ca. 70 $\mathrm{ml}$ of water by warming and stirring the wine-red mixture. The clear solution was then diluted to $100 \mathrm{ml}$. To minimize saponification, the reaction time was kept less than $5 \mathrm{~min}$. The reaction was stopped by acidification with $2 \mathrm{~N} \mathrm{HCl}$. The mixture was extracted with ethyl acetate, and the organic layer was filtered (to remove $S_{8}$ ), washed with water until neutral, and dried $\left(\mathrm{Na}_{2} \mathrm{SO}_{4}\right)$. The solvents were removed under high vacuum to yield $313 \mathrm{mg}$ of a yellow oil, which showed on tic ( $4 \%$ ethanol-benzene) two spots with $\boldsymbol{R}_{f}$ values of 0.48 and 0.55 , respectively. Two fractions $(24 \mathrm{mg}, 8 \%$, and 103 $\mathrm{mg}, 32 \%$ ) could be isolated by preparative tlc (developed one time with $3 \%$ ethanol-benzene and one time with $2 \%$ ethanol-benzene). The product with lower $\boldsymbol{R}_{\mathrm{f}}$ value was found to be the monosulfide 37; the other, the disulfide 38. Both compounds could be further purified by vacuum sublimation $\left(120^{\circ}(0.7 \mathrm{~mm})\right)$ followed by recrystallization from ethanol-hexane for 37 (mp 103.5-104.5 ${ }^{\circ}$ and from ethanol-water for $38\left(\mathrm{mp} 111-113^{\circ}\right)$.

Monosulfide 37: ir $\left(\mathrm{CHCl}_{3}\right)$ 2980, 1730 (ester), 1685 (amide), $1600,1592,1480,1455,1390,1365,1285,1260,1145,1105$, and 1025 $\mathrm{cm}^{-1}$; nmr $\delta 7.70$ (mult, $1 \mathrm{H}, \mathrm{C}_{7}-\mathrm{H}$ ), 7.18 (mult, $3 \mathrm{H}, \mathrm{C}_{4-\sigma}-\mathrm{H}$ ), 4.18, (q, $\left.2 \mathrm{H}, \mathrm{CH}_{2} \mathrm{CH}_{3}\right), 4.07$ (d, $1 \mathrm{H}, \mathrm{C}_{9}-\mathrm{H}_{\alpha}, J_{\alpha \beta}=15 \mathrm{~Hz}, \mathrm{AB}$ spectrum), $3.70\left(\mathrm{~d}, 1 \mathrm{H}, \mathrm{C}_{9}-\mathrm{H}_{\beta}\right), 1.45\left(\mathrm{~s}, 3 \mathrm{H}, \mathrm{C}_{3}-\mathrm{C}_{\alpha} \mathrm{H}_{3}\right), 1.35\left(\mathrm{~s}, 3 \mathrm{H}, \mathrm{C}_{3}-\mathrm{C}_{\beta} \mathrm{H}_{3}\right)$, $1.21\left(\mathrm{t}, 3 \mathrm{H}, \mathrm{CH}_{2} \mathrm{CH}_{3}\right)$; mass spectrum $\left(180^{\circ}\right)$, m/e $291\left(\mathrm{M}^{+}\right), 218$ $\left(\mathrm{M}^{+}-\mathrm{CO}_{2} \mathrm{C}_{2} \mathrm{H}_{5}\right), 203,158,145,144$.

Anal. Calcd for $\mathrm{C}_{15} \mathrm{H}_{17} \mathrm{NO}_{3} \mathrm{~S}: \mathrm{C}, 61.83 ; \mathrm{H}, 5.88 ; \mathrm{N}, 4.81 ; \mathrm{S}$, 11.00. Found: C, 61.73; H, 5.82; N, 4.54; S, 10.76 .

Disulfide 38: ir $\left(\mathrm{CHCl}_{3}\right)$ 2980, 1732 (ester), 1650 (amide), 1595 , $1475,1455,1390,1368,1284,1130,1100$, and $1025 \mathrm{~cm}^{-1} ; \mathrm{nmr} \delta 8.20$ (mult, $1 \mathrm{H}, \mathrm{C}_{7}-\mathrm{H}$ ), 7.15 (mult, $3 \mathrm{H}, \mathrm{C}_{4-6}-\mathrm{H}$ ), 4.18 (q, $2 \mathrm{H}, \mathrm{CH}_{2} \mathrm{CH}_{3}$ ), 4.03 (d, $1 \mathrm{H}, \mathrm{C}_{9}-\mathrm{H}_{\alpha}, J_{\alpha \beta}=17 \mathrm{~Hz}, \mathrm{AB}$ spectrum), $3.49\left(\mathrm{~d}, 1 \mathrm{H}, \mathrm{C}_{9-}\right.$ $\left.\mathrm{H}_{\beta}\right), 1.50\left(\mathrm{~s}, 3 \mathrm{H}, \mathrm{C}_{3}-\mathrm{C}_{\alpha} \mathrm{H}_{3}\right), 1.34\left(\mathrm{~s}, 3 \mathrm{H}, \mathrm{C}_{3}-\mathrm{C}_{\beta} \mathrm{H}_{3}\right), 1.20(\mathrm{t}, 3 \mathrm{H}$, $\left.\mathrm{CH}_{2} \mathrm{CH}_{3}\right)$; mass spectrum $\left(180^{\circ}\right), \mathrm{m} / \mathrm{e} 323\left(\mathrm{M}^{+}\right), 291\left(\mathrm{M}^{+}-\mathrm{S}\right), 259$ $\left(\mathrm{M}^{+}-\mathrm{S}_{2}\right), 252,250\left(\mathrm{M}^{+}-\mathrm{CO}_{2} \mathrm{C}_{2} \mathrm{H}_{5}\right), 218$ (base peak), 203, 172, $158,145,144$.

Anal. Calcd for $\mathrm{C}_{15} \mathrm{H}_{17} \mathrm{NO}_{3} \mathrm{~S}_{2}$ : C, 55.70; $\mathrm{H}, 5.30 ; \mathrm{N}, 4.33 ; \mathrm{S}$, 19.82. Found: C, 55.93; H, 5.17; N, 4.39; S, 19.50 .

One $5-\mathrm{ml}$ aliquot was treated with $20 \mathrm{ml}$ of an aqueous ammonium sulfide solution ( $7 \%$ ). Reaction conditions and work-up were

(50) According to IUPAC rules the nomenclature for $\mathbf{3 7}$ and 38 should be 2,3,9,9a-tetrahydro-3-keto-9,9-dimethyl-9a-carbethoxythiazolo[3,2-a]indole and 3,4,5,6,10,10a-hexahydro-4-keto-10,10-dimethyl10a-carbethoxy-1,2,5-dithiazino[5,6-a]indole, respectively. For convenience we use the names above. the same as described above. After preparative tlc, $80 \mathrm{mg} \mathrm{(27 \% )} \mathrm{of}$ monosulfide 37 andd $40 \mathrm{mg}$ (12.4\%) of disulfide 38 were isolated.

Two other 5-ml aliquots were allowed to react with an aqueous solution of sodium monosulfide ( $20 \mathrm{ml}$ of a $1.1 \mathrm{M}$ solution), or freshly prepared sodium thiocarbonate ${ }^{51}(20 \mathrm{ml}$ of a $1.1 \mathrm{M}$ solution), respectively. Reaction conditions and work-up were as described above. Crude material was purified by vacuum sublimation $\left(110^{\circ}\right.$ $(0.7 \mathrm{~mm})$ ) (material that sublimed at a lower temperature was found to be starting material 17) and recrystallization from ethanol-water to yield $120(40 \%)$ and $123 \mathrm{mg}(42 \%)$, respectively, of the monosulfide 37. Tlc of the crude material showed only traces of the disulfide 38 .

The last aliquot was allowed to react with $20 \mathrm{ml}$ of a $1.1 \mathrm{M}$ aqueous solution of freshly prepared sodium tetrasulfide. The latter was prepared analogous to the preparation of $\mathrm{Na}_{2} \mathrm{~S}_{2}$ from $10.2 \mathrm{~g}$ $(0.33 \mathrm{~mol})$ of powdered sulfur and $26 \mathrm{~g}(0.11 \mathrm{~mol})$ of $\mathrm{Na}_{2} \mathrm{~S} \cdot 9 \mathrm{H}_{2} \mathrm{O}$. Reaction conditions and work-up were the same as described above. After preparative tlc, $42 \mathrm{mg}(14 \%)$ of 37 and $154 \mathrm{mg}$ (47\%) of 38 could be isolated besides $26 \mathrm{mg}(12 \%)$ of the starting material 17 .

Conversion of Disulfide 38 into Monosulfide 37. A solution of $13 \mathrm{mg}\left(4.1 \times 10^{-2} \mathrm{mmol}\right)$ of 38 and $22 \mathrm{mg}\left(8.4 \times 10^{-2} \mathrm{mmol}\right)$ of triphenylphosphine in $1 \mathrm{ml}$ of absolute ethanol was kept, wrapped in aluminum foil, at room temperature for 20 days. The rate of reaction was monitored by tlc. The solvent was removed and the residue subjected to preparative tlc (developed two times, $3 \%$ ethanolbenzene), to yield $9.5 \mathrm{mg}\left(3.25 \times 10^{-2} \mathrm{mmol}, 80 \%\right)$ of 37 . Identification was based upon mass spectrometric and ir data.

$N$-Trifluoroacetyl- $\alpha$, $\alpha$-dichlorosarcosyl Chloride (44). The synthesis of this compound (bp 54-58 $(40 \mathrm{~mm})$ ) is described elsewhere. ${ }^{41}$

2-Carbethoxy-3,3-dimethyl-9-methyliminoindolino[2,1- $b]$ thiazolidinone-8 (49). The addition product of $1.52 \mathrm{~g} \mathrm{(7} \mathrm{mmol)} \mathrm{of} 17$ and $3.8 \mathrm{~g}(14 \mathrm{mmol})$ of 44 in $25 \mathrm{ml}$ of dry benzene was prepared as described for the preparation of 30 (stirred for $16 \mathrm{hr}$ ) and yielded $3.86 \mathrm{~g}$ of a light yellow oil. To an ice-cold solution of this oil in $30 \mathrm{ml}$ of dry diglyme was added quickly an ice-cold, freshly prepared aqueous solution of sodium tetrasulfide $(40 \mathrm{ml}, 44 \mathrm{mmol}$, prepared as described for the synthesis of $\mathbf{3 7}$ and $\mathbf{3 8}$ ). The reaction mixture was kept at $0^{\circ}$ and stirred for $5 \mathrm{~min}$, after which it was extracted with ethyl acetate. The organic layer was dried $\left(\mathrm{Na}_{2} \mathrm{SO}_{4}\right)$ and the solvent removed to yield $1.94 \mathrm{~g}$ of a dark brown oil; $0.65 \mathrm{~g}$ of this oil was subjected to preparation tlc on five plates (developed two times with $4 \%$ ethanol-benzene) to yield $192 \mathrm{mg}(0.88 \mathrm{mmol}, 38 \%)$ of starting material and $270 \mathrm{mg}$ of a still impure, ninhydrin-positive material. The latter was rechromatographed on five plates as before yielding $220 \mathrm{mg}(0.7 \mathrm{mmol}, 30 \%)$ of crystalline material (ninhydrin-positive) which could be further purified by vacuum sublimation at $100^{\circ}(0.5 \mathrm{~mm}): \quad$ tlc ( $5 \%$ ethanol-benzene), one spot $\boldsymbol{R}_{\mathrm{f}} 0.41$. A small sample was crystallized from slowly evaporating chloroform: mp 101-103'; ir $\left(\mathrm{CHCl}_{3}\right)$ 2960, 1730 (ester), 1705 (amide), 1645 (methylimino), 1475, 1455, 1390, and $1290 \mathrm{~cm}^{-1}$; $\mathrm{nmr} \delta 7.88$ (mult, $1 \mathrm{H}, \mathrm{C}_{7}-\mathrm{H}$ ), 7.22 (mult, $3 \mathrm{H}, \mathrm{C}_{4-6}-\mathrm{H}$ ), 4.15 (q, $2 \mathrm{H}, \mathrm{CH}_{2} \mathrm{CH}_{3}$ ), $3.46\left(\mathrm{~s}, 3 \mathrm{H}, \mathrm{NCH}_{3}\right), 1.51\left(\mathrm{~s}, 3 \mathrm{H}, \mathrm{C}_{3}-\mathrm{C}_{\alpha} \mathrm{H}_{3}\right), 1.23\left(\mathrm{~s}, 3 \mathrm{H}, \mathrm{C}_{3}-\mathrm{C}_{\beta} \mathrm{H}_{3}\right)$, $1.18\left(\mathrm{t}, 3 \mathrm{H}, \mathrm{CH}_{2} \mathrm{CH}_{3}\right)$; mass spectrum $\left(160^{\circ}\right)$, m/e $318\left(\mathrm{M}^{+}\right), 302$ $\left(\mathbf{M}^{+}-\mathrm{CH}_{4}\right), 274\left(\mathrm{M}^{+}-\mathrm{OC}_{2} \mathrm{H}_{5}\right), 259\left(274-\mathrm{CH}_{3}\right), 245\left(\mathbf{M}^{+}-\right.$ $\mathrm{CO}_{2} \mathrm{C}_{2} \mathrm{H}_{5}$, base peak), $230\left(245-\mathrm{CH}_{3}\right), 218,204,202$, etc.

2-Carbethoxy-3,3-dimethyl-9-methylaminoindolino[2,1- $b$ ] thiazolidinone-8 (51 and 52). To a solution of $285 \mathrm{mg}(0.9 \mathrm{mmol})$ of the Schiffs base 49 in $5 \mathrm{ml}$ of absolute ethanol at room temperature was added a trace of bromocresol green; $2 \mathrm{~N}$ methanolic $\mathrm{HCl}$ was added until the indicator turned yellow, and $200 \mathrm{mg}(3.2 \mathrm{mmol})$ of sodium cyanoborohydride was added with stirring. Additional $\mathrm{HCl}-$ methanol solution was added to maintain the yellow color. Stirring was continued for $10 \mathrm{~min}$. The solution was poured into $50 \mathrm{ml}$ of ice-cold $0.1 \mathrm{~N} \mathrm{NaOH}$, saturated with $\mathrm{NaCl}$, and extracted twice with ice-cold ethyl acetate. The combined organic layers were dried $\left(\mathrm{Na}_{2} \mathrm{SO}_{4}\right)$ and concentrated in vacuo to give $288 \mathrm{mg}(0.9$ mmol, $100 \%$ ) of a colorless oil, which showed only one spot on tlc (5\% ethanol-benzene, $R_{\mathrm{f}} 0.38$, ninhydrin-positive): ir $\left(\mathrm{CHCl}_{3}\right)$ 3350 (weak, broad, NH), 2980, 2940, 2800, 1730 (ester), 1705 (amide), $1605,1590,1480,1460,1395,1370,1290$, and $1265 \mathrm{~cm}^{-1}$. nmr $\delta$ 7.81 (mult, $1 \mathrm{H}, \mathrm{C}_{7} \mathrm{H}$ ), 7.21 (mult, $3 \mathrm{H}, \mathrm{C}_{4-6}-\mathrm{H}$ ), $5.65\left(\mathrm{~s}, 2 / 3 \mathrm{H}, \mathrm{C}_{9}-\mathrm{H}\right.$ of 51), $5.29\left(\mathrm{~s}, 1 / 3 \mathrm{H}, \mathrm{C}_{9}-\mathrm{H}\right.$ of 52), $4.19\left(\mathrm{q}, 2 \mathrm{H}, \mathrm{CH}_{2} \mathrm{CH}_{3}\right), 2.54$ (2 singlets, separation $1.5 \mathrm{~Hz}, 3 \mathrm{H}, \mathrm{NCH}_{3}$ ) $, 1.49,1.34$, and 1.25 (overlapping singlets, $\mathrm{C}_{3}-\mathrm{CH}_{3}$ in 51 and 52), 1.34 and $1.22\left(2 \mathrm{t}, \mathrm{CH}_{2} \mathrm{CH}_{3}\right.$ of 51 and 52), 1.92 (broad, $1 \mathrm{H}, \mathrm{NH}$ ); mass spectrum $\left(160^{\circ}\right) \mathrm{m} / \mathrm{e}$ $320\left(\mathrm{M}^{+}\right), 279,275\left(\mathrm{M}^{+}-\mathrm{OC}_{2} \mathrm{H}_{5}\right), 264,247\left(\mathrm{M}^{+}-\mathrm{CO}_{2} \mathrm{C}_{2} \mathrm{H}_{5}\right), 245$, $234,230,219,218,202,192,178,175,149,146$ (base peak).

Rearrangement of 51 into 55 and 56 . A solution of $40 \mathrm{mg}(0.126$

(51) D. J. Martin and C. C. Greco, J. Org. Chem., 33, 1275 (1968). 
mmol) of the mixture of 51 and 52 in $5 \mathrm{ml}$ of absolute ethanol was heated in a sealed ampoule at $108^{\circ}$ for $24 \mathrm{hr}$ and then at $125^{\circ}$ for $16 \mathrm{hr}$. Tlc ( $6 \%$ ethanol-benzene) showed the presence of only two products, the starting material and a product with larger $\boldsymbol{R}_{\mathrm{f}}$. The solvent was removed and the brown oily residue subjected to preparative tlc (developed three times with $5 \%$ ethanol-benzene), to yield $26 \mathrm{mg}(65 \%)$ of "starting material" and $14 \mathrm{mg}(35 \%)$ of isomerized product: tlc ( $6 \%$ ethanol-benzene) only one spot, $R_{\mathrm{f}}$ 0.50; ir $\left(\mathrm{CHCl}_{3}\right) 3400$ (sharp, $\mathrm{NH}$ ), 2980, 2940, 2860, 1730 (ester), 1640 (amide), 1600, 1525, 1480, 1460, 1395, and $1370 \mathrm{~cm}^{-1}$; $\mathrm{nmr} \delta$ 8.15 (mult, $1 \mathrm{H}, \mathrm{C}_{T}-\mathrm{H}$ ), 7.20 (mult, $3 \mathrm{H}, \mathrm{C}_{4-\sigma}-\mathrm{H}$ ), 5.50 (broad singlet, $1 \mathrm{H}, \mathrm{C}_{2}{ }^{\prime}-\mathrm{H}$ ), 4.17 (q, $2 \mathrm{H}, \mathrm{CH}_{2} \mathrm{CH}_{3}$ ), 3.23 and 3.13 (2 singlets, sepa- rated $5 \mathrm{~Hz}, 3 \mathrm{H}, \mathrm{N}-\mathrm{CH}_{3}$ ), 2.0 (broad $\mathrm{S}, 1 \mathrm{H}, \mathrm{NH}$ ), 1.47 and 1.29 (2 singlets, $\left.6 \mathrm{H}, \mathrm{CH}_{3} \mathrm{CCH}_{3}\right), 1.29\left(\mathrm{t}, 3 \mathrm{H}, \mathrm{CH}_{2} \mathrm{CH}_{3}\right)$; mass spectrum $\left(160^{\circ}\right), m / e 320\left(\mathrm{M}^{+}\right)$, identical with that for 51 and 52, except for a stronger signal at $\mathrm{m} / \mathrm{e} 304\left(\mathrm{M}^{+}-\mathrm{CH}_{4}\right)$ and a weaker one at $\mathrm{m} / \mathrm{e} 247$ $\left(\mathrm{M}^{+}-\mathrm{CO}_{2} \mathrm{C}_{2} \mathrm{H}_{5}\right)$ and 245 .

. The nmr spectrum of the isolated "starting material" showed a change in that the ratio of the two signals from the $\mathrm{C}_{9}$-proton was reversed (now $\delta 5.65 / 5.29=1: 2$ ), indicating that only the cis enantiomers 51 have been isomerized.

Acknowledgment. We are indebted to Professor R. J. F. Nivard for reading the manuscript. 